\title{
Primary diagnosis and surveillance of white spot syndrome virus in wild and farmed crawfish (Procambarus clarkii, P. zonangulus) in Louisiana, USA
}

\author{
W. A. Baumgartner ${ }^{1, *}$, J. P. Hawke ${ }^{1}$, K. Bowles ${ }^{1}$, P. W. Varner $^{2}$, K. W. Hasson ${ }^{2}$ \\ ${ }^{1}$ Louisiana State University School of Veterinary Medicine, Department of Pathobiological Sciences, Skip Bertman Drive, \\ LSU, Baton Rouge, Louisiana 70803, USA \\ ${ }^{2}$ Texas Veterinary Medical Diagnostic Laboratory, PO Drawer 3040, College Station, Texas 77841, USA
}

\begin{abstract}
This is the first report of natural white spot syndrome virus (WSSV) infection in wild and large-scale farmed crawfish. In the spring of 2007, 3 crawfish farms experienced heavy mortality in ponds populated by Procambarus clarkii and P. zonangulus. Histological examination revealed findings consistent with severe viral infection characterized by numerous intranuclear inclusions in ectodermal and mesodermal tissues. Samples tested by in situ hybridization, injection bioassay in Litopenaeus vannamei, and PCR (nested and real time) were all positive for WSSV. Samples were sent to the National Veterinary Services Laboratory in Ames, Iowa, USA, where WSSV was verified. Subsequently, a multi-parish survey of 184 sites in Louisiana (including farm and wild basin samples) using real-time PCR determined that $>60 \%$ of sites sampled were positive for WSSV, including wild basin samples.
\end{abstract}

KEY WORDS: White spot syndrome virus · WSSV · Crawfish · Crayfish · Procambarus clarkii · Procambarus zonangulus $\cdot$ Real-time PCR $\cdot$ Immunohistochemistry

\section{INTRODUCTION}

For the past $16 \mathrm{yr}$, the white spot syndrome virus (WSSV) has been a serious and devastating pathogen of farmed shrimp worldwide, spreading from Taiwan to Asia, and then to Central, South, and North America (Zuidema et al. 2004). WSSV is currently the only member of both the Whispovirus genus and the Nimaviridae family and can infect $>90$ species of aquatic crustaceans (Sánchez-Martínez et al. 2007, Escobedo-Bonilla et al. 2008). While mortality in penaeid species can reach $100 \%$ within 7 to $10 \mathrm{~d}$, investigations in other crustacean species have determined that in many cases infected animals do not die, but may serve as reservoirs for the pathogen in ecosystems (Zuidema et al. 2004, Sánchez-Martínez et al. 2007). Thus far, study of WSSV in crawfish has largely been due to its suitability as an experimental model (Van Hulten \& Vlak 2001, Jiravanichpaisal et al. 2004,
Du et al. 2006, 2007, Li et al. 2006, Yan et al. 2007), and there are published reports of experimental infection in various crawfish species (Procambarus clarkii, Cherax destructor albidus, Pacifastacus leniusculus and Astacus astacus). These collective findings indicate that WSSV is capable of significant morbidity and mortality in crawfish (Maeda et al. 2000, Shi et al. 2000, Edgerton 2004, Jiravanichpaisal et al. 2004). To our knowledge, there is only 1 report of a natural WSSV outbreak in crawfish (P. clarkii, Orconectes punctimanus), which caused severe disease in a feeder population (crawfish used in the diets of zoo residents) maintained at the National Zoological Park in Washington, D.C., USA (Richman et al. 1997).

In the spring of 2007, 3 farms in St. Martin and Vermilion parishes, Louisiana, USA, reported significant mortalities in their crawfish ponds characterized by $>90 \%$ mortality in traps, which are designed to capture large adults. Of the individuals still alive in the 
traps, all were lethargic and dying, with dead crawfish present along the pond bank as well. Low numbers of crawfish were seen with blotchy to confluent white spots on the dorsal abdomen. Adjacent ponds were not noticeably affected (separated by $6 \mathrm{~m}$ in some cases). Dead and dying crawfish (Procambarus clarkii and P. zonangulus) were submitted to the Aquatic Diagnostic Laboratory of the Louisiana Animal Disease Diagnostic Laboratory (LADDL; Louisiana State University School of Veterinary Medicine) for examination. Case samples were initially processed for light microscopy, in situ hybridization (ISH), shrimp bioassay, and nested PCR. Testing confirmed WSSV infection. Samples were sent to the National Veterinary Services Laboratory in Ames, Iowa, USA, where WSSV was verified. Subsequent statewide WSSV surveillance of crawfish culture ponds and wild stock was conducted using real-time PCR.

\section{MATERIALS AND METHODS}

Tissue processing for histology. Recently deceased Procambarus clarkii and P. zonangulus were fixed in Davidson's solution for 24 to $48 \mathrm{~h}$ and then transferred to $80 \%$ ethanol. Tissues from approximately $20 P$. clarkii and $2 P$. zonangulus were then manually sectioned, embedded in paraffin, and stained with hematoxylin and eosin (H\&E) using standard protocols by the Louisiana State University Histology Laboratory. Tissues from cases of $P$. clarkii culture pond mortalities in 2005 and 2006 (2 total cases) were examined as well.

In situ hybridization. Microscope slides displaying suspect WSSV lesions (from cases in 2007, 2006, 2005) were selected for ISH processing. An ISH assay was conducted using capillary gap technology with the manual MicroProbe ${ }^{\mathrm{TM}}$ work station (Fisher-Scientific), based on published guidelines (Chenggis \& Unger 1993, Latimer et al. 1997, Ramis et al. 1998) with modifications, using a WSSV-specific digoxigenin-labeled probe generated by PCR with Lo's primers (Lo et al. 1996) and the Dig DNA labeling mix (Roche Diagnostics) according to the manufacturer's instructions. Briefly, $5 \mu \mathrm{m}$ paraffin-embedded tissue sections were mounted onto positive-charged silanized slides (ProbeOn Plus ${ }^{\circledR} ;$ Fisher Scientific), deparaffinized in xylene washes, and rehydrated in graded ethanol solutions. Slides were paired and inserted 'face to face' into a MicroProbe slideholder to create a capillary refill gap for subsequent sequential filling with solutions. Sections were digested with Proteinase $\mathrm{K}\left(100 \mu \mathrm{g} \mathrm{ml}^{-1}\right.$ in phosphate-buffered saline) for $8 \mathrm{~min}$ at $37^{\circ} \mathrm{C}$ in the MicroProbe incubator, followed by post-fixation in $0.4 \%$ paraformaldehyde solution for $10 \mathrm{~min}$ at $4^{\circ} \mathrm{C}$. Hybridization entailed simultaneously denaturing the tissue and probe by heating the slides charged with the hybridization solution containing the WSSV-specific digoxigenin-labeled probe to $100^{\circ} \mathrm{C}$ for $10 \mathrm{~min}$, followed by a $2 \mathrm{~h}$ incubation at $42^{\circ} \mathrm{C}$. Unbound probe was removed by passing the tissue sections through a series of stringency salt washes $(2 \times$ to $0.2 \times \mathrm{SSC})$ with the final soak at $37^{\circ} \mathrm{C}$. To detect bound DIG-labeled probe, slides were incubated for $30 \mathrm{~min}$ in alkaline phosphatase-labeled anti-digoxigenin antibody solution (Roche Diagnostics) at $37^{\circ} \mathrm{C}$. In the final detection step, sections were incubated in a chromagen development solution (NBT/BCIP) at $37^{\circ} \mathrm{C}$ for $30 \mathrm{~min}$. Slides were counterstained in Bismarck Brown stain $(0.5 \%)$, coverslipped, and examined microscopically for intranuclear probe uptake (blue-black coloration).

Bioassay. Two $75 \mathrm{l}$ glass aquaria containing $\sim 20 \mathrm{l}$ of artificial seawater (Crystal Sea Marinemix ${ }^{\mathrm{TM}}, 30 \mathrm{ppt}$ salinity, $23^{\circ} \mathrm{C}$ ) were each stocked with 12 Litopenaeus vannamei juveniles (mean weight $1 \mathrm{~g}$ ) following intramuscular injection (20 to $30 \mu$ shrimp $^{-1}$ ) with 1 of 2 inocula $(0.2 \mu \mathrm{m}$ filtered $2 \%$ saline or $0.2 \mu \mathrm{m}$ filtered crawfish gill tissue homogenate) according to established methods (Hasson et al. 2006). Tank 1 contained saline-injected controls, and Tank 2 contained those injected with the tissue homogenate. The tanks were covered to prevent escape and were continuously aerated. Individuals were fed a pelleted ration (Ziegler No. 4 pellets) ad lib once per day and were monitored 3 times per day. Up to 6 moribund individuals were collected and preserved using Davidson's fixative and processed for routine H\&E histological analysis following established methods (Bell \& Lightner 1988). Tail tissue and or additional whole moribund shrimp were frozen for subsequent PCR analysis (at the Texas Veterinary Medical Diagnostic Laboratory) utilizing the World Organization for Animal Health (OIE) recommended nested procedure (Lo et al. 1996).

Nested PCR. For the initial virus identification (at the LADDL), gill tissue and pleopods were harvested from suspected WSSV-positive individuals and stored at $-20^{\circ} \mathrm{C}$. Sample homogenization for extraction was performed using a Tissuelyser (Qiagen) ball mill. Briefly, $50 \mathrm{mg}$ gill or pleopod samples were homogenized in $600 \mu \mathrm{l}$ OIE lysis buffer with a $5 \mathrm{~mm}$ steel bead for $2 \mathrm{~min}$ at $25 \mathrm{~Hz}$. The resulting homogenate was extracted according to the OIE recommended protocol (OIE 2003).

The nested PCR was initially performed as recommended by the OIE white spot disease protocol (OIE 2003). Subsequent nested PCR work substituted the PuReTaq ${ }^{\mathrm{TM}}$ Ready-to-Go ${ }^{\mathrm{TM}}$ PCR Beads mix (GE Healthcare). Final $25 \mu \mathrm{l}$ reactions contained $10 \mathrm{mM}$ Tris- $\mathrm{HCl}, \mathrm{pH} 9,50 \mathrm{mM} \mathrm{KCl}, 1.5 \mathrm{mM} \mathrm{MgCl}_{2}, 200 \mu \mathrm{M}$ of each nucleotide, 2.5 units of PuReTaq DNA polymerase, and 25 pmol of each primer (Table 1). Cycling 
Table 1. Primers used for nested and quantitative PCR

\begin{tabular}{|c|c|c|c|}
\hline Primer & Sequence $\left(5^{\prime} \rightarrow 3^{\prime}\right)$ & Expected product & Source \\
\hline \multicolumn{4}{|l|}{ Outer nested } \\
\hline 146F1 & ACTACTAACTTCAGCCTATCTAG & $1447 \mathrm{bp}$ & OIE (2003) \\
\hline 146R1 & TAATGCGGGTGTAATGTTCTTACGA & & \\
\hline \multicolumn{4}{|l|}{ Inner nested } \\
\hline $146 \mathrm{~F} 2$ & GTAACTGCCCCTTCCATCTCCA & $941 \mathrm{bp}$ & OIE (2003) \\
\hline 146R2 & TACGGCAGCTGCTGCACCTTGT & & \\
\hline \multicolumn{4}{|l|}{ Decapod } \\
\hline $143 \mathrm{~F}$ & TGCCTTATCAGCTNTCGATTGTAG & $848 \mathrm{bp}$ & OIE (2003) \\
\hline $145 \mathrm{R}$ & TTCAGNTTTGCAACCATACTTCCC & & \\
\hline \multicolumn{4}{|l|}{ Quantitative } \\
\hline WSS1011F & TTGTCCCGTCCTCATCTCAG & $68 \mathrm{bp}$ & Durand \& Lightner (2002) \\
\hline WSS1079R & \multicolumn{3}{|l|}{ GCTGCCTTGCCGGAAATTA } \\
\hline Probe & \multicolumn{3}{|c|}{ (6-Fam) AGCCATGAAGAATGCCGTCTATCACACA (BHQ-1) } \\
\hline
\end{tabular}

conditions were altered to 30 cycles at $94^{\circ} \mathrm{C}$ for $30 \mathrm{~s}$, $62^{\circ} \mathrm{C}$ for $30 \mathrm{~s}$, and $72^{\circ} \mathrm{C}$ for $30 \mathrm{~s}$; ending with $72^{\circ} \mathrm{C}$ for $2 \mathrm{~min}$. The first reaction used $1 \mu \mathrm{l}$ of DNA eluate, and $1 \mu \mathrm{l}$ of the first reaction was amplified in the second reaction. A negative control (no initial template DNA) was included with all PCR runs.

Decapod-specific primers (Table 1) were used to confirm the quality of the DNA template as previously described by OIE, although Amplitaq Gold Taq polymerase (Applied Biosystems) and the manufacturer's $10 \times$ assay buffer containing $15 \mathrm{mM} \mathrm{MgCl}_{2}$ were substituted (OIE protocol).

The PCR products were analyzed by $2 \%$ agarose gel electrophoresis in TAE buffer (0.04 M Tris-acetate, $1 \mathrm{mM}$ EDTA) with $0.6 \mu \mathrm{g} \mathrm{ml}^{-1}$ ethidium bromide. The DNA molecular weight standard 100 bp DNA ladder (New England Biolabs) was used to determine amplicon size.

PCR amplicons were cut from the agarose gel and purified using the MinElute gel extraction kit according to manufacturer's instructions (Qiagen). Direct amplicon sequencing was performed by the GeneLab division of the BioMMED core facility (Louisiana State University School of Veterinary Medicine) using Big Dye Terminator chemistry on the ABI3130 sequence analysis instrument (Applied Biosystems). Sequence data were analyzed using the BioEdit program (freeware, www.mbio.ncsu.edu/BioEdit/bioedit.html), and the identity of the PCR product was checked against the National Institute for Health's National Center for Biotechnology Information (NCBI) GenBank database via BLAST analysis.

Surveillance real-time PCR. For surveillance purposes using real-time PCR, samples of gill tissue (50 mg per individual) were taken from 30 crawfish and pooled. Two pooled samples were analyzed from each farm pond (60 crawfish per pond site), and 4 pooled samples were prepared from the Atchafalaya
Basin sites (120 crawfish per site) for a total of 184 sites. The total number of crayfish tested was $>11000$. Crawfish that could not be immediately harvested were held at $4^{\circ} \mathrm{C}$ or $-20^{\circ} \mathrm{C}$. Tissue pools were homogenized in $1 \mathrm{ml}$ of lysis buffer (4 M urea, $200 \mathrm{mM}$ Tris, $20 \mathrm{mM}$ $\mathrm{NaCl}, 200$ mM EDTA, pH 7.4) in the Tissuelyser with 2 steel beads $(5 \mathrm{~mm})$ for $2 \mathrm{~min}$ at $30 \mathrm{~Hz}$ using $-20^{\circ} \mathrm{C}$ cooled sample holding blocks and $4^{\circ} \mathrm{C}$ lysis buffer. Sample blocks were rotated and homogenized again. Tissue debris was pelleted at $8000 \times g$ for $3 \mathrm{~min}$, and $200 \mu \mathrm{l}$ of supernatant were extracted with the High Pure PCR Template Preparation Kit (Roche Diagnostics) according to the manufacturer's recommended protocol. DNA was recovered in $100 \mu$ l of elution buffer and stored at $-20^{\circ} \mathrm{C}$.

Real-time PCR was performed using a previously described method (Durand \& Lightner 2002) and primers (Table 1). Cycling was performed on an ABI 7500 Fast system (Applied Biosystems) for 2 min at $50^{\circ} \mathrm{C}, 10 \mathrm{~min}$ at $95^{\circ} \mathrm{C}$ followed by 40 cycles of $95^{\circ} \mathrm{C}$ for $15 \mathrm{~s}$, and $60^{\circ} \mathrm{C}$ for $1 \mathrm{~min}$. Data capture was at the extension step.

\section{RESULTS}

\section{WSSV pathology}

Histological findings and ISH results in Procambarus clarkii and P. zonangulus corresponded to typical lesions reported for fulminant WSSV infections in penaeid shrimp, i.e. a majority of cells in ectodermal and mesodermal tissues contained hypertrophied nuclei with variably staining large homogeneous inclusions and marginated chromatin (Lo et al. 1997, Wang et al. 1997). Inclusions were detected within the cuticular epithelium lining the foregut and hindgut, as well as within the heart, muscle, nerve cord, antennal gland 
(coelomosac, labyrinth, and nephridial canal), vas deferens (Fig. 1a), testes (testicular nurse cells; Fig. 1b), hematopoietic tissue, and the connective tissues. Severe cuticular epithelial necrosis was present in some specimens, resulting in separation of large tracts of abdominal soft tissues from the overlying dorsal abdominal cuticle (Fig. 1c). In crawfish with abdominal white spots, the endocuticle on the abdominal dorsum was less than half normal thickness and often highly irregular or had a moth-eaten appearance (Fig. 1d). Necrotic cell debris was multifocally encased in the endocuticle by abnormal cuticular elements. Underlying epithelium was severely distorted by hypertrophied nuclei containing large inclusions, some of which had
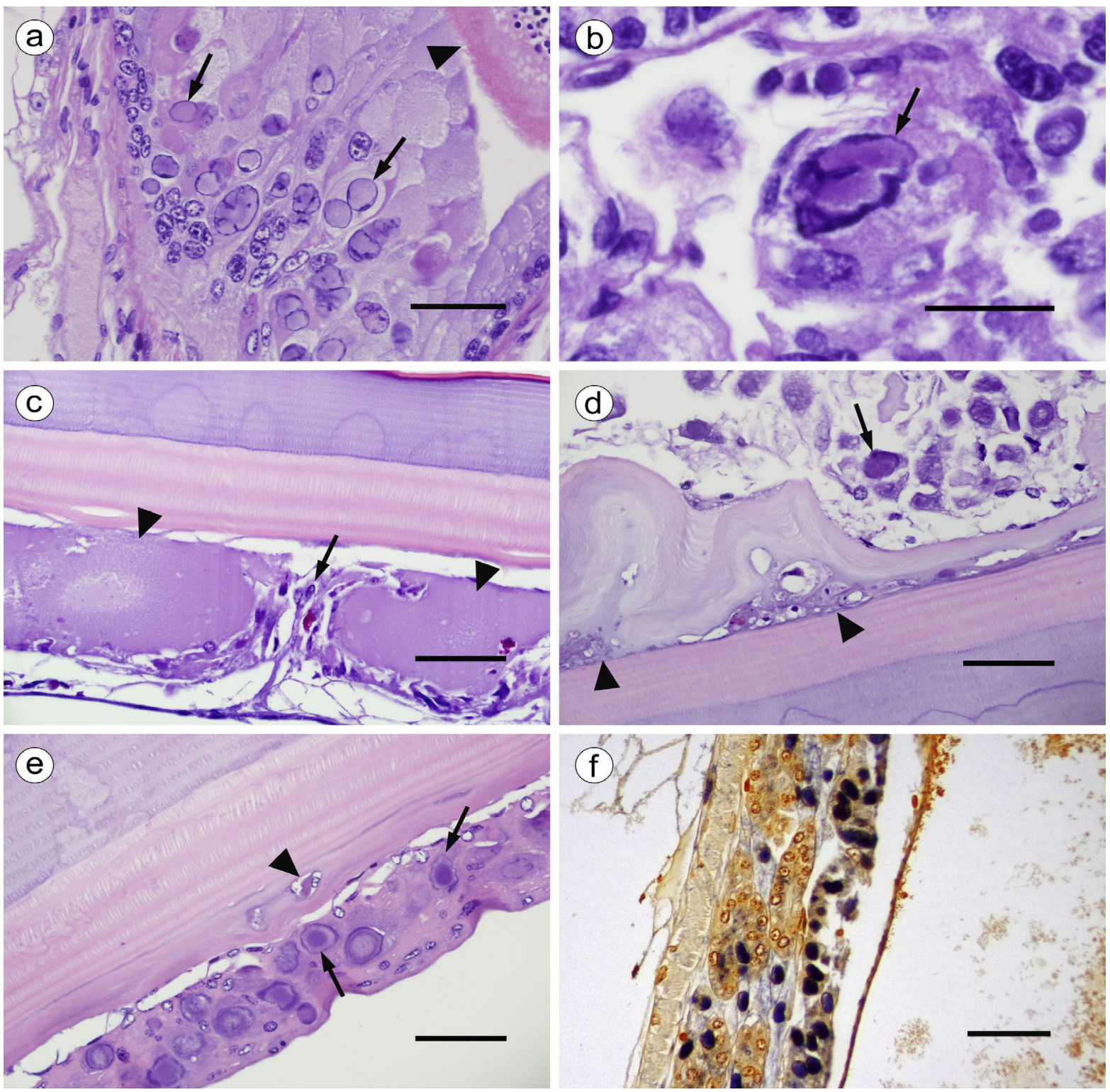

Fig. 1. Procambarus clarkii infected by white spot syndrome virus (WSSV). (a) Vas deferens epithelium nuclei are hypertrophied with large varisized amphophilic inclusions, and marginated chromatin (arrows). A spermatophore with spermatozoa is present in the vas deferens lumen (arrowhead). (b) A hypertrophied nurse cell nucleus contains a large, irregular inclusion (arrow). (c) Dorsal abdominal cuticle epithelium (arrow) is mostly absent due to necrosis, which allows separation of soft tissues from the cuticle. Proteinaceous fluid (arrowheads) fills the newly developed space. (d) Dorsal abdominal inner procuticle is malformed, redundant, and irregular with entrapped necrotic cellular material (arrowheads). Epithelial nuclei are hypertrophied and have inclusions (arrow). (e) Dorsal abdominal cuticle. Cellular debris is trapped in the inner procuticle (arrowhead). The epithelium is dysplastic and contains numerous hypertrophied nuclei with large inclusions and clear halos (arrows, Cowdry type A inclusions). (f) Hindgut epithelium. Intranuclear inclusions in infected cells are demonstrated with a digoxigenin-labeled WSSV-specific probe (blue-black color) via in situ hybridization. All scale bars $=50 \mu \mathrm{m}$, except (b) $(25 \mu \mathrm{m})$ 
peripheral clear halos, or Cowdry type A inclusions (Cowdry 1934; Fig. 1e). In 2 specimens from a severely affected pond, numerous irregular white spots covered the entire body (Fig. 2). Microscopically, these white spots were characterized by full thickness mineralization of intact cuticle. Subjacent to the cuticle, irregular mineralized debris replaced cuticular epithelium (dystrophic mineralization, calcinosis). Overall, white spots were uncommon to rare in affected crawfish. Intranuclear inclusions in cases from 2007 and 2006 stained blue-black by ISH, indicating WSSV-specific probe uptake (Fig. 1f).

\section{Shrimp bioassay}

All 12 Litopenaeus vannamei that were injected with the crawfish tissue homogenate were found moribund or dead within $48 \mathrm{~h}$ post infection. No mortality occurred among the saline-injected group, which was maintained for $5 \mathrm{~d}$ post infection. Histological analysis of 6 moribund tissue homogenate-injected shrimp demonstrated severe widespread WSSV infections. Histological analysis of 6 negative control shrimp sampled upon termination on Day 5 demonstrated mild hemocytic hepatopancreatitis with intralesional extracellular bacteria in 3 of the 6 shrimp. However, no known shrimp viral diseases were detected in these 6 individuals.

\section{Nested PCR}

A subset $(n=10)$ of the initial crawfish specimens was tested by nested PCR (OIE protocol) in conjunction with verified WSSV-infected shrimp tissue (provided by the Texas Veterinary Medical Diagnostic Labora-

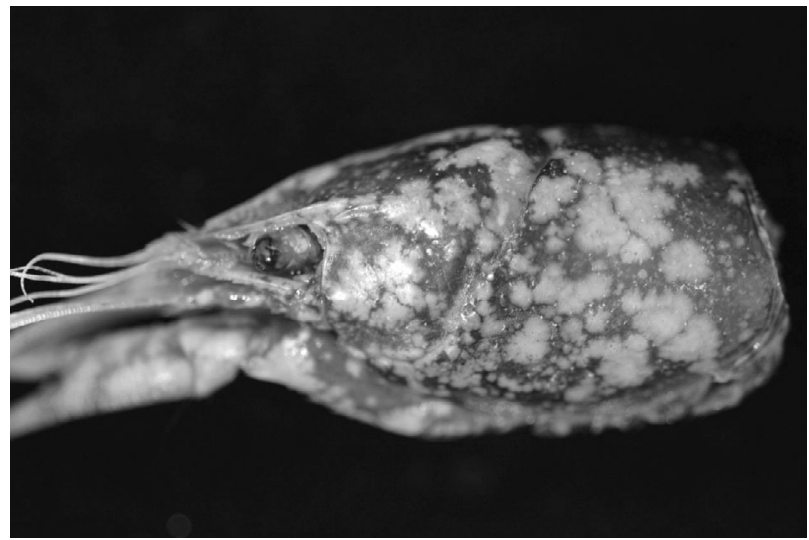

Fig. 2. Procambarus clarkii from a pond severely affected by white spot syndrome virus. Multiple irregular coalescing white spots are dispersed over the entire outer cuticle tory). All samples produced $>500 \mathrm{bp}$ of sequence that had 99 to $100 \%$ identity with WSSV (BLAST analysis). Nested PCR analysis of pleopods from 6 dead WSSVbioassay exposed Litopenaeus vannamei confirmed the presence of WSSV.

\section{Real-time PCR/survey results}

In total, 184 sites representing the major crawfish production areas of Louisiana were sampled; of these, $111(60.33 \%)$ were WSSV positive by real-time PCR (Fig. 3). Positive samples were identified in 13 of 18 parishes tested in southern Louisiana (Fig. 4), with the majority of samples coming from Vermilion, Acadia, and St. Martin parishes, which had $76 \%, 62 \%$, and $73 \%$ positive rates, respectively. Clinical signs of disease (lethargy, death) were seen in 10 ponds, 6 of which were severely affected. The majority of sites tested were from culture ponds or samples at crawfish processors. However, 10 of the sites tested were from the Atchafalaya Basin (wild stock), and of these, 3 were positive, including 1 site where dead crawfish were seen floating in the bayou.

\section{DISCUSSION}

To our knowledge, this account is the first to document WSSV infection in crawfish in a natural habitat and in an area of large-scale crawfish production. Our survey indicates a high prevalence of WSSV infection in farmed and wild crawfish throughout southern Louisiana. Importantly, this region is where the majority of crawfish production occurs, both cultured and wild. As a result, governmental efforts for WSSV containment have been discontinued in Louisiana. Although few negative effects were evident in many of the infected production sites, mortality was severe in a small number of locations. The relative difference in environmental stressors between production sites is a likely cause for variation in morbidity/mortality. However, a more virulent WSSV strain may be present in certain production areas. Also, the prevalence of infected crawfish at these sites cannot be determined since pooled tissue samples were used.

Red swamp crawfish Procambarus clarkii and southern white river crawfish $P$. zonangulus are the commercially important crawfish species in Louisiana and naturally inhabit the swamps and rivers of southern Louisiana. Crawfish production in Louisiana relies almost entirely on earthen ponds with low-intensity methods that are little more than limited control of the natural conditions under which these crawfish thrive in the surrounding swamps. Farmed crawfish may 


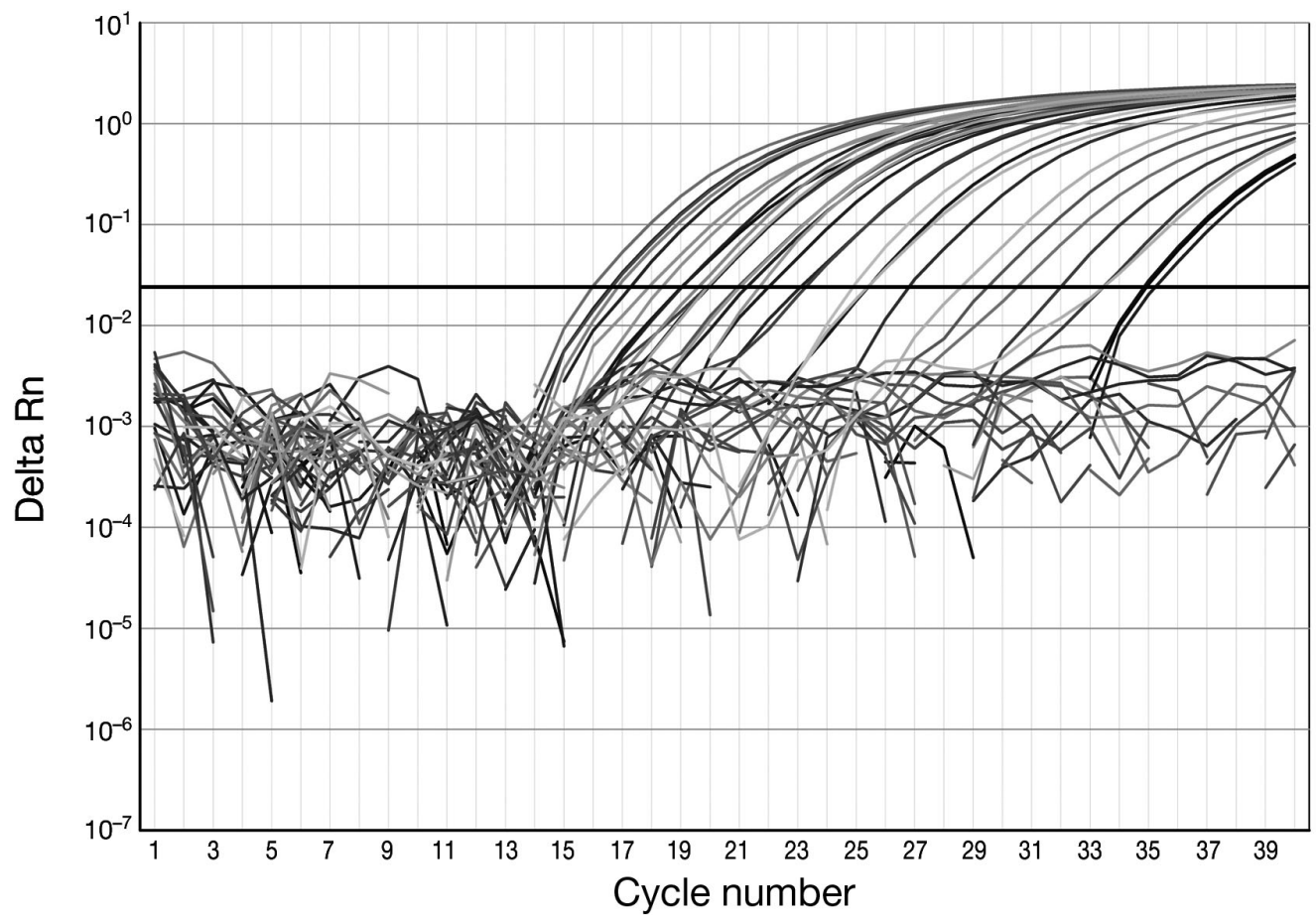

Fig. 3. Real-time PCR plot showing the positive and negative results from crawfish tissue samples. Log $\Delta$ Rn (magnitude of the signal) vs. cycle number. Gray lines represent individual samples. Black horizontal line = threshold

travel between ponds or into waterways and often come into contact with a wide variety of predatory vertebrate and invertebrate organisms. Unlike many other aquaculture industries, crawfish pond population density relies on the reproductive capacity of mature pond residents, which, in turn, is heavily influ- enced by environmental conditions (McClain et al. 2007).

The Louisiana crawfish industry is intimately associated with an area that contains the nation's largest river-bottomland hardwood swamp (Atchafalaya Basin,1800 square miles) as well as the Port of South

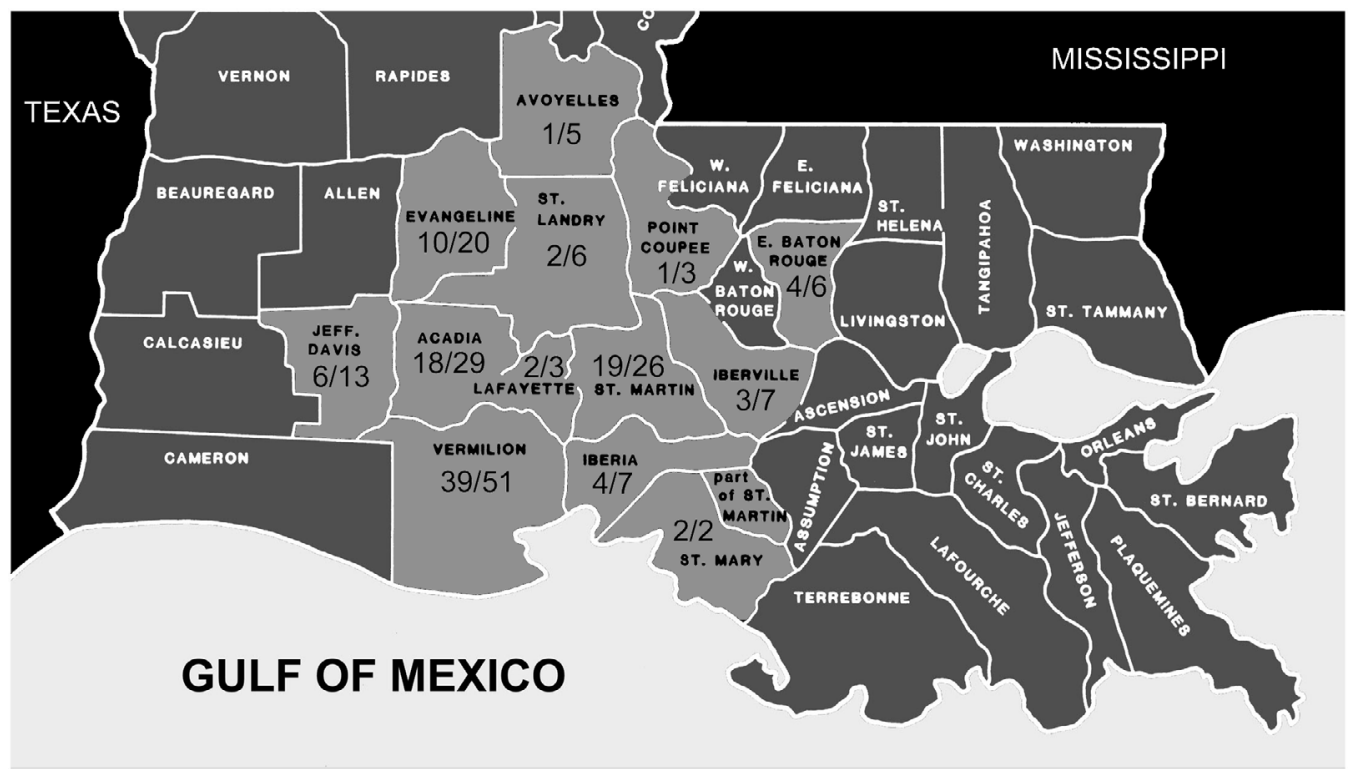

Fig. 4. Political map of southern Louisiana. Parishes in which positive samples were detected are light gray. Fractions indicate positive sites over sites tested in each parish. Two sites from Assumption parish and single sites from Calcasieu, Natchitoches (not shown), Rapides, and St. James parishes were tested and were negative 
Louisiana, the largest port by tonnage in the Western Hemisphere (Beck 1977, Kravitz et al. 2005). Imported commodities travel from Louisiana ports throughout the Mississippi waterway and the eastern USA, and over 1 billion pounds of potentially WSSV-infected shrimp are imported into the USA each year (Kravitz et al. 2005, USDA 2007). The Atchafalaya Basin is a major branch of the Mississippi River and is a major source of human food, with reported annual crawfish harvests alone exceeding 30000 tons in good years (Huner 2002). Several freshwater decapod crustaceans, including at least 9 species of crawfish, at least 2 grass shrimp (Palaemonetes spp.), and Australasian tiger shrimp Penaeus monodon inhabit the Atchafalaya Basin and are in contact with blue crab Callinectes sapidus and a variety of other marine decapods in the estuary (Penn 1959, Beck 1977, USGS 2008). All of these species may serve as carriers of WSSV.

WSSV first appeared in the USA in Texas shrimp production units in 1995 and has since been found in wild Callinectes sapidus, white shrimp Litopenaeus setiferus, and brown shrimp Farfantepenaeus aztecus in the Gulf of Mexico (Hasson et al. 2006). Ship ballast water, farm effluent, shrimp packing-plant waste, and imported bait/commodity shrimp have been shown to be, or have been implicated as, sources of viral transmission. Currently, no federal regulations require shrimp virus screening of imported frozen shrimp (Hasson et al. 2006). With this in mind, it is important to note that Louisiana, in addition to importing bait shrimp from WSSV-positive nations, has several shrimp-packing plants in the area of this investigation. Although speculative, these epidemiological factors provide a relevant potential source of WSSV into this area.

Since no virus was detected histologically in Louisiana crawfish populations in a disease surveillance effort conducted in 2001(McClain et al. 2001), it appears that WSSV arrived in southern Louisiana after 2001 and has spread throughout the region. Archived crawfish tissues were examined, and intranuclear inclusions consistent with WSSV were present in cases from 2005 and from 2006. ISH was able to confirm WSSV in 2006, but not in the 2005 sample (likely due to overfixation of tissues). Overall, the effect of WSSV on the crawfish industry since the initial outbreak has been negligible; however, there is no reliable data collection system for crawfish production. Mild or modest WSSV outbreaks may have gone undetected, considering the nature of crawfish production practices in Louisiana coupled with the relative resistance of Procambarus clarkii to WSSV-related mortality (Wang et al. 1998).

The presence of occasional white-spotted crawfish is due to abnormal cuticular development leading to cuti- cle thinning over the abdomen. Subnormal cuticle deposition is likely due to the effects of WSSV infection on epithelial/cuticle metabolism. It is interesting that cuticular separation due to epithelial necrosis occurs in the same area as the white spot formation. This region of the crawfish may be particularly susceptible to viral effects that manifest themselves grossly.

Two crawfish from affected ponds were seen to have irregular white spots distributed over the entire cuticle. Histologically, spots consisted of full thickness cuticle mineralization with large subjacent aggregates of irregular mineralized debris at the cell-cuticle interface. In regard to the latter aspect, these white spots bore some resemblance to those described in Penaeus monodon (Wang et al. 1999). The epicuticle in these specimens was intact, and no evidence of bacterial infection was seen. With so few examples, the relationship of these spots to WSSV infection is difficult to assess. White spots of this nature have not been previously seen in farmed or wild crawfish in Louisiana (R. McClain \& R. Romaire pers. comm.) Similar to many American penaeid shrimp species, white spots in Procambarus clarkii were uncommon. Note that it is very rare to find spotting in WSSVinfected American penaeids. Spot formation may be relative depending on the species affected; in 1 study, delayed white spot formation associated with experimental WSSV infection in P. clarkii was hypothesized to correlate with the increased thickness of the cuticle (Wang et al. 1998).

In summary, WSSV is now present in a very large decapod crustacean population, which is intensively farmed and, at the same time, widely dispersed in a wild environment inhabited by multiple susceptible species with substantial international human and animal traffic. The degree of injury that WSSV may cause to the Louisiana crawfish industry and to indigenous North American crawfish species remains to be seen.

Acknowledgements. We thank the Lightner Lab, A. Baudena, M. Broussard, T. Conger, C. Crowder, S. DeJean, D. Givler, T. Guedry, M. Littlefield, E. McClellan, H. Moreau, L. Orvin, R. Poston, A. Roy, M. Shirley, G. Tilyou, J. Warg, and J. Wiles for their excellent assistance.

\section{LITERATURE CITED}

Beck LT (1977) Distribution and relative abundance of freshwater macroinvertebrates of the lower Atchafalaya river basin, Louisiana. MS thesis, Louisiana State University, Baton Rouge, LA

Bell TA, Lightner DV (1988) A handbook of normal penaeid shrimp histology. Allen Press, Lawrence, KS

Chenggis ML, Unger ER (1993) Application of a manual capillary action workstation to colorimetric in situ hybridization. J Histotechnol 16:33-38 
Cowdry EV (1934) The problem of intranuclear inclusions in virus diseases. Arch Pathol 18:527-542

Du HH, Li WF, Xu ZR, Kil ZS (2006) Effect of hyperthermia on the replication of white spot syndrome virus (WSSV) in Procambarus clarkii. Dis Aquat Org 71:175-178

Du H, Fu L, Xu Y, Kil Z, Xu Z (2007) Improvement in a simple method for isolating white spot syndrome virus (WSSV) from the crayfish Procambarus clarkii. Aquaculture 262: 532-534

Durand SV, Lightner DV (2002) Quantitative real time PCR for the measurement of white spot syndrome virus in shrimp. J Fish Dis 25:381-389

Edgerton BF (2004) Susceptibility of the Australian freshwater crayfish Cherax destructor albidus to white spot syndrome virus (WSSV). Dis Aquat Org 59:187-193

Escobedo-Bonilla CM, Alday-Sanz V, Wille M, Sorgeloos P, Pensaert MB, Nauwynck HJ (2008) A review on the morphology, molecular characterization, morphogenesis and pathogenesis of white spot syndrome virus. J Fish Dis 31: $1-18$

> Hasson KW, Fan Y, Reisinger T, Venuti J, Varner PW (2006) White-spot syndrome virus (WSSV) introduction into the Gulf of Mexico and Texas freshwater systems through imported, frozen bait-shrimp. Dis Aquat Org 71:91-100

Huner JV (2002) Procambarus. In: Holdich DM (ed) Biology of freshwater crayfish. Blackwell, Oxford

> Jiravanichpaisal P, Söderhäll K, Söderhäll I (2004) Effect of water temperature on the immune response and infectivity pattern of white spot syndrome virus (WSSV) in freshwater crayfish. Fish Shellfish Immunol 17:265-275

Kravitz AR, Campanella R, Schiavinato L (2005) State management plan for aquatic invasive species in Louisiana. State of Louisiana, Baton Rouge, LA, p 1-160

Latimer KS, Niagro FD, Williams OC, Ramis A, Goodwin MA, Ritchie BW, Campagnoli RP (1997) Diagnosis of avian adenovirus infections using DNA in situ hybridization. Avian Dis 41:773-782

Li LJ, Yuan JF, Cai CA, Gu WG, Shi ZL (2006) Multiple envelope proteins are involved in white spot syndrome virus (WSSV) infection in crayfish. Arch Virol 151:1309-1317

Lo CF, Leu JH, Ho CH, Chen CH and others (1996) Detection of baculovirus associated with white spot syndrome (WSBV) in penaeid shrimps using polymerase chain reaction. Dis Aquat Org 25:133-141

Lo CF, Ho CH, Chen CH, Liu KF and others (1997) Detection and tissue tropism of white spot syndrome baculovirus (WSBV) in captured brooders of Penaeus monodon with a special emphasis on reproductive organs. Dis Aquat Org 30:53-72

Maeda M, Itami T, Mizuki E, Tanaka R and others (2000) Red swamp crawfish (Procambarus clarkii): an alternative experimental host in the study of white spot syndrome virus. Acta Virol 44:371-374

McClain R, Romaire R, Huner J, Hawke J, Edgerton B (2001) Assessment of health and reproduction of crawfish brood-

Editorial responsibility: Grant Stentiford, Weymouth, UK stock and implications for production. Louisiana Crawfish Promotion and Research Board, Baton Rouge, LA

McClain R, Romaire R, Lutz CG, Shirley M (2007) Louisiana crawfish production manual. Louisiana State University Agricultural Center, Baton Rouge, LA

OIE (2003) White spot disease. In: OIE (ed) OIE manual of diagnostic tests for aquatic animals. OIE, Paris, p 285-297

Penn GH (1959) An illustrated key to the crawfishes of Louisiana with a summary of their distribution within the state. Tulane Stud Zool 7:3-20

Ramis A, Latimer KS, Gibert X, Campagnoli R (1998) A concurrent outbreak of psittacine beak and feather disease virus, and avian polyomavirus infection in budgerigars (Melopsittacus undulatus). Avian Pathol 27:43-50

Richman LK, Montali RJ, Nichols DK, Lightner DV (1997) A newly recognized fatal baculovirus infection in freshwater crayfish. In: Baer CK (ed) Proc Am Assoc Zoo Vet, p 262-264

Sánchez-Martínez JG, Aguirre-Guzmán G, Mejía-Ruíz H (2007) White spot syndrome virus in cultured shrimp: a review. Aquacult Res 38:1339-1354

Shi Z, Huang C, Zhang J, Chen D, Bonami JR (2000) White spot syndrome virus (WSSV) experimental infection of the freshwater crayfish, Cherax quadricarinatus. J Fish Dis 23:285-288

USDA (2007) Assessing infectious disease emergence potential in the U.S. aquaculture industry phase 1: U.S. aquaculture industry profile. USDA/APHIS, Fort Collins, CO

USGS (2008) Nonindigenous aquatic species database. Available at http://nas.er.usgs.gov

Van Hulten MCW, Vlak JM (2001) Identification and phylogeny of a protein kinase gene of white spot syndrome virus. Virus Genes 22:201-207

Wang CS, Tang KFJ, Kou GH, Chen SN (1997) Light and electron microscopic evidence of white spot disease in the giant tiger shrimp, Penaeus monodon (Fabricius), and the kuruma shrimp, Penaeus japonicus (Bate), cultured in Taiwan. J Fish Dis 20:323-331

> Wang YC, Lo CF, Chang PS, Kou GH (1998) Experimental infection of white spot baculovirus in some cultured and wild decapods in Taiwan. Aquaculture 164:221-231

Wang YG, Hassan MD, Shariff M, Zamri SM, Chen X (1999) Histopathology and cytopathology of white spot syndrome virus (WSSV) in cultured Penaeus monodon from peninsular Malaysia with emphasis on pathogenesis and the mechanism of white spot formation. Dis Aquat Org 39: $1-11$

Yan DC, Dong SL, Huang J, Zhang JS (2007) White spot syndrome virus (WSSV) transmission from rotifer inoculum to crayfish. J Invertebr Pathol 94:144-148

Zuidema D, van Hulten MCW, Marks H, Witteveldt J, Vlak JM (2004) Virus-host interactions of white spot syndrome virus. In: Leung KY (ed) Current trends in the study of bacterial and viral fish and shrimp diseases. World Scientific, Singapore, p 237-255

Submitted: August 29, 2008; Accepted: February 23, 2009 Proofs received from author(s): April 28, 2009 